\title{
The Effect of Political Connection on Private Firm Performance Research based on the Perspective of Regional Diversity and Industry Heterogeneity
}

\author{
Jianfeng Lü ${ }^{1, a}$, Anqi Gao ${ }^{2, b}$ \\ ${ }^{1}$ College of Finance and Trade, Bohai University, Jinzhou, 121013, China \\ ${ }^{2}$ Jinzhou Power Supply Company, State Grid Liaoning Electric Power Supply Co., LTD., Jinzhou, 121100, \\ China \\ alujianfeng9999@126.com, bangel12333233@126.com
}

Keywords: political connection; private firm; performance; regional diversity

\begin{abstract}
The relationship between government and enterprises is the major issues in the economic reform and development, and Political Connection (PC) is the embodiment of the relationship between government and enterprises. As a result, the paper will select Chinese private enterprises as the research sample, exploring the mechanism of action of PC of enterprise performance in Chinese context. The main research conclusions are as follows: PC is one of the major factors which influence firm's performance. The degree of the local government intervention has a positive moderating effect on the relationship between the existence of PC and firm's performance; the threshold of industry access has a positive moderating effect on the relationship between the existence of PC and firm's performance.
\end{abstract}

\section{Introduction}

Entrepreneurs as government posts, employing current and former officials and establishing personal relationships with government officials are the important channels of PC. It can help the enterprises require "scarce" resources for direct access to enterprise development (Peng, Luo, 2000), and obtain policy resources through influencing government policy making indirectly.

Therefore PC has played an important role in accelerating the development of enterprises and promotes economic growth. In the early stage of the transformation, quite a number of private enterprise by means of PC, seized market opportunities, overcome the market and institution blank, so that achieved profit growth and became the main driving force to promote the growth of our economy under the condition under the condition less market competitive advantage, opportunity-driven growth is still the main strategic orientation of many private enterprises in China (Chen Z Y, Wu X B,2006). But as the change of the institutional environment, PC plays a more complicated role in the development of enterprises. It will bring too much system pressure, social costs, and even produce "rent-seeking" and corruption. In addition, the performance of political connected enterprises with a lot of resources from the government is not always higher than that of non-political connected enterprises, it means that PC may cause the waste of social resources, in turn, will affect the quality of economic development. Under the new normal economic background, the society will not only concern with economic growth, but also pay attention to economic quality. Therefore, to study the effect of PC on enterprise performance based on Chinese situation is beneficial clarifying the boundaries between government and enterprise and improving quality of economy. $\square$

Existing literature focus mainly on what the PC has brought to the enterprise, meaning that the benefits or costs of PC for the enterprises. Little literature involved the constraint of the mechanism about pc affecting enterprise performance, meaning that what and how impact the relationship between PC and corporate performance, but this is precisely what the key issues in related research.

At present, China's economy is in a critical period of transformation, which the market economic system has yet to be perfected. Due to exist the phenomenon of government direct allocation of 
resources and the social network to replace the market resources allocation, companies tend to seek to establish "relationship" with the government, in order to avoid the risks of external environment during the transitional period of uncertainty. Academic debate about PC can affect enterprise performance origin has long. Some scholars from the financing facilities, preferential tax, government subsidies and industry access perspective, study found a PC can help enterprises obtain policy resources, to improve enterprise performance. Another part of the scholars emphasized that PC strengthen the control of the government to enterprise, increased operating costs and the social burden, reduces the enterprise performance. This paper argues that the following issues worthy of further study: one is the PC index may be one of the important factors that cause the ambiguity. One is the insufficient for external situation factors. Enterprise development was born in its institutional environment, embedded in the political system, economic system, market characteristics, corporate governance environment; PC with different country, region, industry, and property rights shows the characteristics of heterogeneity, characterized by strong context dependence. Experience in the foreign related theory and application in practice, must consider the applicability of the theory, namely the characteristics of PC. Therefore, focusing on corporate ownership type, enterprise industry and regional factors as the premise, study the mechanism of PC affect enterprise performance, is likely to explain related research conclusion inconsistencies make more reasonable explanation. This article will be the first to study PC and its strength characteristics influence on enterprise performance, then study the interaction based on regional institutional environment and the heterogeneity of industry perspective.

\section{Theory analysis of Political connection influence enterprise performance}

The purpose of enterprises to establish PC is to gain political interests and economic interests. Enterprise's political interests and economic interests must be achieved by legality mechanism. The organization's survival depends not only on market environment, but also on composed of regulation, rules and cultural cognition system environment. From all dimensions of the system of legitimacy, in terms of regulatory pressure, PC can help companies overcome the government regulation of industry barriers to entry, the lower industry enters the mouth sill; In terms of pressure, PC can help companies overcome the imbalance of regional development and regional system environment, legal environment, financial environment brought by the imperfect "grab" the hand of the infringement; "In terms of cognitive load, under the background of the current system of China, the network is a kind of cultural phenomenon and system coexist. Imperfect institutional environment can limit the growth of enterprises to adopt traditional strategy, which is based on interpersonal relationship network resources strategic attention. As a PC reputation mechanism, PC can improve enterprise competition ability. From the point of economic interests, PC brought Christmas for enterprise information and convenient preferential tax, government subsidies, as well as policy information resources, the PC that the government has played a" supporting the hand ", and brings economic benefits for the enterprise.

From the point of political interests, PC can protect enterprises property rights from the damage of local government. A lot of people will be "relationship" to view and operation as one of the most important asset, and may be asked to take on more political and social goals, PC even becoming "umbrella" of executives to get occupational safety. Some scholars found that some entrepreneurs for their own political identity or promotion goal, may spend a certain amount of rent-seeking cost, therefore will sacrifice the enterprise economic benefits, increase transaction costs, hind the promotion enterprise's improvement of productivity and performance. At this point, PC play the role of the government's "plundering hand". Although PC enterprises will take the social costs of local government and rent-seeking costs, but the essence of enterprise profit maximization will become its efforts through multi-channel access to government resources, making PC benefit is greater than the associated costs. Although entrepreneur hunger for political status can also affect the economic interests of companies. But entrepreneurs are driven by internal factors, and rely more on certain institutional foundations.

The entrepreneur's enthusiasm for political participation is not constant. The demand of private 
entrepreneurs in our country is inverted $U$ shape, which means that the enthusiasm of the entrepreneur's participation in politics will fade after a certain degree. Corporate performance will increase significantly as the company's large shareholders or corporate executives enter the political arena. Arranging a politician or an entrepreneur associated with the government to go to a public company's board of directors can improve corporate performance and resilience. After the succession of executives with government backgrounds, companies are significantly more valuable than those who do not have a government background.

Establish PC to enhance the political influence of the company, which is to influence government decisions through PC. In terms of PC, the enterprise has a PC executives, the more the number of the enterprise from the government are more channels of access to information and resources, the stronger the ability to overcome the information asymmetry, can get, the more available resources, the better business performance will be. In the depth of PC, the more politically connected executives rank in the government, the stronger the ability to influence the government's policymaking. PC is conducive to the social and governmental recognition of enterprises and the impact on other enterprises' power. PC enhances the ability of businesses to influence governments and markets and improve competitive advantage. Entrepreneurs and political identity and positively related to the scale of the enterprise, the greater of enterprise scale the greater of likelihood to elected provincial or CPPCC members. Entrepreneur's political identity and its level has become a signal to display enterprise strength and quality. PC reduces the correlation degree of information asymmetry between enterprises and financial institutions, so as to facilitate enterprise get financing from financial institutions.

\section{The research of political connection effect enterprise performance under the regional diversity views}

Regional institutional environment is one of the most important constraints in the development of private enterprises. The degree of formal system and the degree of dependence of enterprises on government resources directly influence the behavior pattern of enterprises.

First of all, in the past 30 years of reform and opening up process, due to the system arrangement, historical evolution, endowment and geographical location, the regional differences in the institutional environment in our country, shows the characteristics of uneven, diversification. Mainly manifested in the degree of government intervention in the market and enterprise, the degree of the development of non-state economy, development and legal system environment, product market development degree of the growing degree. $\square$

In gradual, decentralization and empirical formula of economic transformation, system and policy of the Chinese government at all levels have been through differentiation or take turns driving the different ownership, different areas, different industries, and even different strength of the enterprise reform, and given to the different protection policy, further widened the gap between regions. The southeast coastal area marketization degree are more reasonable and improve than the central and western regions, in the southeast coastal area the government less to intervention or violation of private enterprises, enterprise property right protection level higher, financial market is more mature. Therefore, it is great significance to analyze the institutional diversity of the region.

$\square$ Second, the PC of companies depends on their reliance on government resources. This dependence is based on several aspects: one is the degree of government grasp scarce resources; another is the role of the government in allocating resources; it is the costs and benefits of establishing a PC; Due to the reform of social and economic transformation in our country carried on the idea of political centralization and economic decentralization. Economic decentralization has given local governments considerable economic residual rights and control. Local governments, which have the incentive to regulate local resources, have a motive for maximizing their own interests, so competition between local governments is fierce.

Under the condition of transition economy, China's economic system and legal system is not perfect, the market mechanism and government intervention are affect the enterprise behavior and performance. Local government policy changes will lead to enterprise development facing the 
uncertainty risk, the enterprise's competitive position will be as the change of government policy changes, then on the performance of enterprises promote or inhibit effect. Because of the government controls the important resources which influence of enterprise competition, and have the function of configuration of resources, therefore, the degree of government intervention in the market will directly affect the enterprise strategy.

Current official assessment mode, make the Local protectionism is widespread, rent-seeking behavior is more prevalent. In these areas, many private companies are more vulnerable to discriminated by policies. Due to the formal system are not perfect, officials not only execute the formal system with flexible, but also through setting threshold arbitrary fines, any form of intervention in the enterprise development. In these areas, the informal system has a greater impact on the practitioners of policy. To prevent the "grab" the hands of the government, private enterprises will prefer to gain legitimacy through PC to protect, and use the PC embedded regional networks, access to its development needs social resources, thus received government subsidies policy.

\section{In the perspective of industry heterogeneity, the political connection influences the performance of enterprises}

PC is a signal transmission mechanism which can reduce information asymmetry and help companies to get more loans. PC is a good reputation mechanism, the bank take PC as a guaranteed the mortgaged property, and is willing to provide enterprises with more long-term loans. Banks tend to provide lending to politically connected companies. Domestically, politically connected private companies can get more and longer term bank loans. PC of corporate debt financing have a significant impact, extended the loan period, gives the enterprise financing incentives, thus reducing the enterprise financing constraints, reduce the financing threshold and promoted the performance of the enterprise.

Effective property rights protection system is the basis of market exchange and the establishment of market economy system. The legal environment in one area determines its level of protection of enterprise property rights. The effective protection of enterprise property right is conducive to the establishment and realization of enterprise management strategy, thereby promoting the further development of private economy. In the transition economy, an imperfect legal system creates an uncertain property protection for private property, which leaves the enterprise with a greater risk of growing up. In areas where the legal system is more imperfect, the more vulnerable companies are to discrimination.

Because the economy is in transition period, private enterprises in our country must face to financing difficulties, high short-term debt, liquidity risk, etc. Bank lending is the main form of debt financing for private enterprises. Relative to state-owned enterprises, the economic risks are higher because of the smaller private sector. Regional system environment is different, the degree of local government intervention and the motive of building PC are different. In regions where local governments have intervened, where financial development is low, and where laws and regulations are patchy, there is a stronger incentive to be politically connected.

The higher of enterprise entry barrier, the less the number of enterprises in the industry competition, enterprise's profit performance is better. Most of the industries with strong profitability are state-supported or have an administrative monopoly. Government regulation is divided into administrative and economic control because of the difference between the basis and the way of expression. Administrative regulation is based on the discrimination of ownership, which is aimed at limiting the development of non-state components and thus safeguarding the monopoly benefits of state-owned components. Economic regulation is aimed at the market main body, such as market segmentation, price discrimination, cartel non-market and the economic behavior of the market, so as to maintain an orderly competition order. Along with the advancement of reform and opening up and the speeding up of marketization, gradually transforms the administrative controls into economic controls.

The tighter the government's grip on resources, the more common PC is. Because industry access 
standards are not fully quantified, it is make the black box operation possible. By establishing the channel of PC to reduce the negative effect of information asymmetry, the social public trust is a better choice for the survival and development of the enterprise. In a competition industry, the more competitive of the market, the number of enterprises.is greater Industry competition intensified, the role of market mechanism is greater, the enterprise's desire to build a PC at this time will be lower, the political relation intensity, is conducive to clarify the relationship between enterprise and government, enterprise performance may be worse.

\section{Conclusion}

In this paper, the main research conclusions are as follows:

(1)PC is one of the major factors which influence firm's performance. The relationship between government and enterprises linked by PC will impact the possibility of the evolution and symbiosis of firms' return and risk. Generally, performance of firms with PC is better than those with none. And the effect of strength characteristics of PC on corporate performance is significant with different effect direction. Breadth of PC negatively influences performance while depth of PC positively, and with the higher significant level. $\square$

(2) Based on the perspective of regional diversity, results show that a).the degree of the local government intervention has a positive moderating effect on the relationship between the existence of PC and firms' performance and on the relationship between depth of PC and performance, b). the local legal system environment plays a negative moderating role on the relationship between the existence of PC and firms' performance, and it can strengthen the negative relationship between breadth of PC and performance, while the moderating role on the depth of PC is not significant, c).the level of financial development has a negative moderating effect on the relationship between the existence of PC and firms' performance, while the moderating effect on the breadth of PC can strengthen the negative relationship between breadth of PC and performance.

(3) Based on the perspective of industry heterogeneity, we find that a). The threshold of industry access has a positive moderating effect on the relationship between the existence of PC and firms, performance and on the relationship between depth of PC and performance, while the moderating effect on the breadth of PC can strengthen the negative relationship between breadth of PC and performance, b).the intensity of industry $\mathrm{R} \& \mathrm{D}$ plays a positive moderating effect on the relationship between the existence of PC and firms, performance and on the relationship between depth of PC and performance c).The liability ratio of industry asset has a positive moderating effect on the relationship between depth of PC and performance, while the moderating effect on the existence of PC and the breadth of PC is insignificant.

\section{References}

[1] Chaney P K, Faccio M, Parsley D. The quality of accounting information in politically connected firms [J]. Journal of Accounting and Economics, 2011, 51(1): 58-76.

[2] Goldman E,Rocholl J,So J. Do politically connected boards affect firm value [J].Review of Financial Studies,2009,22(6):2331-2340.

[3]Porter M. Corporate strategy[J]. New York. New York, NY, 1980.

[4] Voth, H.J, T. Ferguson. Betting on Hitler: The Value of Political Connections in Nazi Germany[J]. Quarterly Journal of Economics,2008,123(1):101-137.

[5] Faccio M. Differences between Politically Connected and Nonconnected Firms: A Crow Country Analysis [J]. Financial Management, 2010,39(3):905-928. 